\title{
Proto-Oncogene Mas
}

National Cancer Institute

\section{Source}

National Cancer Institute. Proto-Oncogene Mas. NCI Thesaurus. Code C17064.

Proto-oncogene Mas (325 aa, $\sim 37 \mathrm{kDa}$ ) is encoded by the human MAS1 gene. This

protein is involved in angiotensin binding and G protein-coupled receptor signaling. 